\title{
QUALITY OF LIFE RELATED TO BREAST CANCER IN WOMEN IN POSTMENOPAUSE: A SYSTEMATIC REVIEW
}

\author{
CALIDAD DE VIDA RELACIONADA CON EL CÁNCER DE MAMA EN MUJERES EN \\ POSMENOPAUSIA: UNA REVISIÓN SISTEMÁTICA

\section{QUALIDADE DE VIDA RELACIONADA AO CÂNCER DE MAMA EM MULHERES NA PÓS- MENOPAUSA: REVISÃO SISTEMÁTICA}

\begin{abstract}
Alexsandra Ribeiro Ferreira ${ }^{1}$, Laura Faustino Gonçalves ${ }^{2}$, Karina Mary de Paiva ${ }^{3}$, Ana Ines Gonzales ${ }^{4}$, Patricia
\end{abstract} Haas $^{5}$

Submetido em: 23/06/2021

e26471

Aprovado em: 14/07/2021

\begin{abstract}
Objective: To verify the quality of life related to post-menopausal breast cancer in women using HT, through a systematic review. Methods: For the selection of studies, the combination [(Hormone Replacement Therapy) AND (use) AND (breast cancer) AND (menopausal women) AND (quality of life) AND (randomized controlled trial)) was used]. The search was performed in the Medline, LILACS, Bireme, SciELO, ScienceDirect and Google Scholar databases as a gray search. Randomized articles were included, without language restriction, published between January 2010 and March 2020, which obtained a minimum score of 10 on the modified scale of the literature. Articles that did not have a title, abstract or body of the article related to the research objective were excluded. Result: 1217 articles were retrieved, however two articles met the inclusion criteria, being classified as high quality. It has been observed that HT increases the risk of developing breast cancer during post-menopause. Conclusion: HT combined with different progestogens improves symptoms caused by post menopause. However, one should evaluate the advantages and disadvantages of use among women, especially when they present some risk factor for developing the disease. Lower rates of breast cancer risk were observed when $\mathrm{HT}$ administered with estrogen alone.
\end{abstract}

KEYWORDS: Hormone replacement therapy. Breast cancer. Menopause. Quality of life. Women's health.

\section{RESUMEN}

Objetivo: Verificar la calidad de vida relacionada con el cáncer de mama en mujeres posmenopáusicas que utilizan TH, a través de una revisión sistemática. Métodos: Para la selección del estudio, se utilizó la combinación [(terapia de reemplazo hormonal) $Y$ (uso) $Y$ (cáncer de mama) Y (mujeres menopáusicas) Y (calidad de vida) Y (ensayo clínico aleatorizado)]. La búsqueda se realizó en las bases de datos Medline, LILACS, Bireme, SciELO, ScienceDirect y Google Scholar en el formulario de búsqueda gris. Se incluyeron artículos aleatorizados sin restricción de idioma, publicados entre enero de 2010 y marzo de 2020, con una puntuación mínima de 10 en la escala modificada de la literatura. Se excluyeron los artículos que no contenían el título, resumen o cuerpo del artículo relacionado con el objetivo de la investigación. Resultado: se recuperaron 1217 artículos, pero dos artículos cumplieron los criterios de inclusión y se clasificaron como de alta calidad. Se ha demostrado que la TH aumenta

\footnotetext{
${ }^{1}$ Acadêmica do Curso de Fonoaudiologia da Universidade Federal de Santa Catarina - UFSC - Florianópolis (SC), Brasil.

${ }^{2}$ Graduanda em Fonoaudiologia pela Universidade Federal de Santa Catarina-UFSC; Eng. Agronômico Andrei Cristian Ferreira, Bairro: Trindade; CEP 88040-900 -Florianópolis -SC, Brasil.

3 Professora Adjunta do Departamento de Fonoaudiologia, Curso de Graduação em Fonoaudiologia da Universidade Federal de Santa Catarina - UFSC - Florianópolis (SC), Brasil.

${ }^{4}$ Doutora e Fisioterapeuta UDESC - Eng.b Agronômico Andrei Cristian Ferreira, Bairro: Trindade - Florianópolis SC, Brasil.

5 Professora Adjunta do Departamento de Fonoaudiologia, Curso de Graduação em Fonoaudiologia da Universidade Federal de Santa Catarina - UFSC - Florianópolis (SC), Brasil.
}

RECIMA21 - Ciências Exatas e da Terra, Sociais, da Saúde, Humanas e Engenharia/Tecnologia 


\section{RECIMA21 - REVISTA CIENTÍFICA MULTIDISCIPLINAR ISSN 2675-6218}

QUALITY OF LIFE RELATED TO BREAST CANCER IN WOMEN IN POSTMENOPAUSE: A SYSTEMATIC REVIEW Alexsandra Ribeiro Ferreira, Laura Faustino Gonçalves, Karina Mary de Paiva, Ana Ines Gonzales, Patricia Haas

el riesgo de desarrollar cáncer de mama durante las mujeres posmenopáusicas. Conclusión: la TH combinada con diferentes progestágenos mejora los síntomas post menopáusicos. Sin embargo, se deben evaluar las ventajas y desventajas de su uso entre las mujeres, especialmente cuando presentan algún factor de riesgo para el desarrollo de la enfermedad. Se observaron tasas de riesgo de cáncer de mama más bajas cuando se administró TH solo con estrógeno.

PALABRAS CLAVE: Terapia hormonal substitutiva. Cáncer de mama. Menopausia. Calidad de vida. Salud de la mujer.

\section{RESUMO}

Objetivo: Verificar a qualidade de vida relacionada ao câncer de mama na pós-menopausa em mulheres usuárias de TH, por meio de revisão sistemática. Métodos: Para a seleção do estudo, a combinação [ (terapia de reposição hormonal) AND (uso) AND (câncer de mama) AND (mulheres na menopausa) AND (qualidade de vida) AND (ensaio clínico randomizado) ] foi usada. A busca foi realizada nas bases de dados Medline, LILACS, Bireme, SciELO, ScienceDirect e Google Scholar na forma de busca cinza. Foram incluídos artigos randomizados, sem restrição de idioma, publicados entre janeiro de 2010 e março de 2020, com pontuação mínima de 10 na escala modificada da literatura. Foram excluídos os artigos que não continham título, resumo ou corpo do artigo relacionado ao objetivo da pesquisa. Resultado: Foram recuperados 1217 artigos, porém dois artigos atenderam aos critérios de inclusão e foram classificados como de alta qualidade. Foi demonstrado que a TH aumenta o risco de desenvolver câncer de mama durante a pós-menopausa. Conclusão: A TH combinada com diferentes progestagênios melhora os sintomas causados pela pós-menopausa. Porém, deve-se avaliar as vantagens e desvantagens do uso entre as mulheres, principalmente quando estas apresentam algum fator de risco para o desenvolvimento da doença. Taxas mais baixas de risco de câncer de mama foram observadas quando o TH foi administrado apenas com estrogênio.

PALAVRAS-CHAVE: Terapia de reposição hormonal. Câncer de mama. Menopausa. Qualidade de vida. Saúde da mulher.

\section{INTRODUCTION}

Breast cancer is the most frequent cancer in women, impacting 2.1 million women each year, and is also responsible for the highest number of cancer-related deaths among women in the world ${ }^{[1]}$. In Brazil, according to the José Alencar Gomes da Silva National Cancer Institute (2019), breast cancer is the most prevalent among malignant neoplasms that affect women, it is estimated that in Brazil we have about 66,280 new cases for each year of the 2020-2022 triennium, being more prevalent above 50 years of age ${ }^{[2]}$. Without considering non-melanoma skin tumors, female breast cancer occupies the first most frequent position in all Brazilian regions.

It is known that with advancing age the female body undergoes physiological changes, with perimenopause being the moment when the body begins a process of changes that precede menopause. This transition lasts an average of two to five years, depending on the individuality of each female organism ${ }^{[3]}$. Menopause is a normal and physiological event in a woman's life, characterized by the permanent suspension of menstruation and the interruption of the hormones estrogen and progesterone. Although menopause occurs naturally due to biological changes resulting from advancing 


\section{RECIMA21 - REVISTA CIENTÍFICA MULTIDISCIPLINAR ISSN 2675-6218}

QUALITY OF LIFE RELATED TO BREAST CANCER IN WOMEN IN POSTMENOPAUSE: A SYSTEMATIC REVIEW Alexsandra Ribeiro Ferreira, Laura Faustino Gonçalves, Karina Mary de Paiva, Ana Ines Gonzales, Patricia Haas

age, it can trigger in an artificial way, after specific clinical or surgical procedures that may lead to the stop of hormonal production ${ }^{[3,4]}$.

This life cycle of women, usually occurs between 40 and 55 years of age, the same period that according to studies, is also the most prevalent for the diagnosis of breast cancer, and accompanies a series of signs and symptoms that directly affect quality of life $(Q O L)^{[2,5]}$. Among the main complaints presented by women at this stage are reduced libido, menstrual irregularities, hot flushes, excessive sweating, headache, tiredness, weakness, irritability, mood changes and depression ${ }^{[6]}$.

Hormone Therapy (HT) is one of the therapies used as an ally in this process, as it helps in clinical conditions and can affect the QOL of patients ${ }^{[4]}$. However, although $\mathrm{HT}$ helps to attenuate some symptoms and indicate an improvement in QoL during menopause, this therapeutic method also offers some inherent risks, such as an increase in the risk indexes of myocardial infarction, strokes and breast cancer ${ }^{[7]}$.

Some studies point to HT as one of the probable causes of an increase in the incidence of breast cancer among women, however, there is still no uniformity of opinions in the scientific community [8-10]. According to the Brazilian Consensus on Menopause Hormone Therapy, HT is not recommended for women with a family history of cancer, since its use may trigger the onset or reappearance of the lesion [11].

With the evident increase in the number of breast cancer cases in the female population, as well as, given the women's lack of knowledge about the effects of $\mathrm{HT}$, the present study aimed to verify the quality of life of women with breast cancer during menopause or post-menopausal women undergoing hormone therapy, through a systematic review. Additionally, we sought to consider the complications and risks inherent to health when using $\mathrm{HT}$.

\section{METHODS}

\section{Registration Protocol}

The systematic review was conducted according to the recommendations of the Preferred Reporting Items for Systematic Reviews and Meta-Analyzes (PRISMA) ${ }^{[12]}$.Searches for scientific articles were conducted by two independent researchers in the electronic databases Medline (Pubmed) ScienceDirect, SciELO, LILACS and BIREME, without restrictions on location or languages, and must have been published from January 2010 to May 2020.

The research was structured and organized in the form PICOS (Table 1), which represents an acronym for Target Population, Intervention, Comparison, Outcomes, Study. The descriptors were selected from the Health Sciences Descriptors (DeCS) and Medical Subject Heading Terms (MeSH) dictionary, in view of their great use by the scientific community for indexing articles in the PubMed database. 


\section{RECIMA21 - REVISTA CIENTÍFICA MULTIDISCIPLINAR} ISSN 2675-6218

QUALITY OF LIFE RELATED TO BREAST CANCER IN WOMEN IN POSTMENOPAUSE: A SYSTEMATIC REVIEW Alexsandra Ribeiro Ferreira, Laura Faustino Gonçalves, Karina Mary de Paiva, Ana Ines Gonzales, Patricia Haas

Table 1. Description of the PICOS strategy.

\begin{tabular}{c|c|c}
\hline Acronym & Definition & description \\
\hline $\mathbf{P}$ & Patient or problem & Women in menopause \\
\hline I & Intervention & Using Hormone Therapy \\
\hline C & Control or comparison & $\begin{array}{c}\text { Healthy women who do not use } \\
\text { any therapeutic methods }\end{array}$ \\
\hline $\mathbf{O}$ & Outcome & $\begin{array}{c}\text { Impact on quality of life of women } \\
\text { using Hormone Therapy }\end{array}$ \\
\hline S & Type of study & Longitudinal studies \\
\hline
\end{tabular}

At first, proposals were made for searches on MEDLINE (via PubMed) (https://www.ncbi.nlm.nih.gov/pubmed/) the search strategy used to retrieve the articles was: [((Hormone Replacement Therapy)) AND ((breast cancer)) AND ((menopausal women)) AND ((quality of life)) AND ((randomized controlled tria/[pt] OR controlled clinical trial[pt] OR randomized controlled trials[mh] OR random allocation[mh] OR double-blind method[mh] OR singleblind method[mh] OR clinical tria/pt] OR clinical trials[mh] OR ("clinical trial"[tw]) OR ( sing $^{*}[\mathrm{tw}]$ OR doub/*[tw] OR treb/* $[\mathrm{tw}]$ OR trip/*tw]) AND (mask*[tw] OR blind*[tw])) OR ("latin square"[tw]) OR placebos[mh] OR placebo*[tw] OR random*[tw] OR research design[mh:noexp] OR follow-up studies[mh] OR prospective studies[mh] OR cross-over studies[mh] OR contro/ $\left[\right.$ [tw] OR prospectiv* $\left[\right.$ tw] OR volunteer $\left.{ }^{*}[\mathrm{tw}]\right)$ NOT (anima[mh] NOT human[mh]))].

In view of these descriptors, the adequacy for the other bases used was made ScienceDirect (https://www.sciencedirect.com/) and Latin American and Caribbean Center for Health Sciences Information (BIREME) (https://bvsalud.org/) when needed. In addition, a search was performed on Google Scholar, as a search in gray literature, using the same strategy as the previous databases. For the search in the journal Latin American and Caribbean Literature in Health Sciences (LILACS) (http://lilacs.bvsalud.org/) and Scientific Electronic Library Online (SciELO) (http://www.Scielo.br/) the search strategy was used: [((Hormone Replacement Therapy) AND (use) AND (breast cancer) AND (menopausal women) AND (quality of life))] to retrieve the articles.

\section{Inclusion and exclusion criteria}

The present review included published studies that addressed the QoL of women with breast cancer in the menopause and post-menopause periods, using HT. Period included from 2010 to 2020. There was no restriction on the language for the searches, and the included study was translated when necessary and possible.

To be admitted to the present study, publications should still score higher than 6 in the modified protocol by Pithon et al. (2015) ${ }^{[13]}$., used to assess the methodology quality of studies.

Studies with the following characteristics were excluded: Case reports, cohort studies, screening studies, observational studies, letters to the editor, guidelines, systematic reviews, meta-analyzes and 


\section{RECIMA21 - REVISTA CIENTÍFICA MULTIDISCIPLINAR} ISSN 2675-6218

QUALITY OF LIFE RELATED TO BREAST CANCER IN WOMEN IN POSTMENOPAUSE: A SYSTEMATIC REVIEW Alexsandra Ribeiro Ferreira, Laura Faustino Gonçalves, Karina Mary de Paiva, Ana Ines Gonzales, Patricia Haas

abstracts. Studies that did not describe or were unclear or unavailable were also excluded. Articles published before 2010 and that scored less than six in the literature modified protocol were also excluded from the study. Table 2 represents the inclusion and exclusion criteria applied in this research.

Table 2. Summary of inclusion / exclusion criteria.

\section{Inclusion Criteria}

\begin{tabular}{c|c}
\hline Outline & $\begin{array}{c}\text { Case studies and control } \\
\text { Intervention studies } \\
\text { Cohort studies } \\
\text { Screening studies } \\
\text { Observational studies }\end{array}$ \\
\hline Location & Without restriction \\
\hline Language & Portuguese, English and Spanish \\
\hline Period & January 2013 to July 2020 \\
\hline
\end{tabular}

\section{Exclusion Criteria}

\begin{tabular}{c|c}
\hline Outline & $\begin{array}{c}\text { Literature reviews } \\
\text { Systematic reviews } \\
\text { Meta-analyzes }\end{array}$ \\
Studies & $\begin{array}{c}\text { Unclear studies } \\
\text { Poorly described or inadequate }\end{array}$ \\
\hline Form of publication & Summary only \\
\hline
\end{tabular}

Source: Developed by the authors.

\section{Risk of bias}

The quality of the methods used in the included studies was independently assessed by the reviewers ( $\mathrm{PH}$ and ARF), according to the PRISMA recommendation ${ }^{[12]}$. The assessment prioritized the clear description of the information. At this point, the review was carried out blindly, masking the names of the authors and magazines, avoiding any potential bias and conflict of interest.

\section{Data analysis}

Data extraction for the studies' eligibility process was performed using a form prepared by the researchers in the Excel® 2010 Program, in which the extracted data were initially added by one of the 


\section{RECIMA21 - REVISTA CIENTÍFICA MULTIDISCIPLINAR ISSN 2675-6218}

QUALITY OF LIFE RELATED TO BREAST CANCER IN WOMEN IN POSTMENOPAUSE: A SYSTEMATIC REVIEW Alexsandra Ribeiro Ferreira, Laura Faustino Gonçalves, Karina Mary de Paiva, Ana Ines Gonzales, Patricia Haas

researchers and then checked by the other researcher. For the data obtained from the eligible studies, these were also transported and information was collected regarding: demographic characteristics of the patients included in the study, type of study, frequency, evaluations performed, components evaluated and results obtained.

\section{Selection of studies}

The articles admitted to this systematic review were selected by two independent authors. Initially, the eligibility reviewer (ARF) was calibrated to perform the systematic review by AIG, KMP and $\mathrm{PH}$. After calibration and clarification of doubts, the titles and abstracts were independently examined by two eligibility reviewers (ARF and $\mathrm{PH}$ ), who were not blind to the names of the authors and the journals, those who were potentially eligible were selected and duplicate studies were excluded. Those who presented the title within the scope, but the abstracts were not available, were also obtained and analyzed in full. Articles that did not meet any inclusion criteria were excluded.

Subsequently, the preliminary eligible studies had the full text obtained and evaluated. In specific cases, when the study with potential for eligibility presented incomplete data, the authors could be contacted by email for more information, however there was no need for this research. We selected studies that presented data regarding the quality of life of women with menopausal or post-menopausal breast cancer using hormone therapy. In case of disagreement between evaluators, a third evaluator (AIG) made the decision on the eligibility of the study in question.

\section{RESULTS}

A total of 1217 articles were identified in primary searches. However, when performing the exclusion due to duplicity, 1176 articles remained, and after exclusion by title and abstracts, 52 articles remained. Thus, 12 articles were selected for evaluation in accordance with the title and their revised abstracts. When evaluating the articles in their entirety, two studies met all the proposed inclusion criteria which met the guiding question. No study was included in the analysis after examining the reference lists of the reviewed articles. The divergences were resolved by consensus between the authors or requested for the intervention of a third researcher. This inclusion selection was established according to the recommendations of the Preferred Reporting Intense for Systematic Reviews and Meta-Analyzes (PRISMA). All phases of study selection can be seen in Figure 1.

The total sample, from the sum of the number of subjects in the two selected studies, was 27,422 female individuals. The age of the research participants varied between 42 and 79 years old in both studies.

When evaluating the methodological analysis of the studies, the quality score of the included studies ranged from 11 to 13 points, with an average of 12 points. This score reflects that the quality of the studies included in this systematic review has reached high quality, representing the studies as acceptable for research. 


\section{RECIMA21 - REVISTA CIENTÍFICA MULTIDISCIPLINAR}

\section{ISSN 2675-6218}

QUALITY OF LIFE RELATED TO BREAST CANCER IN WOMEN IN POSTMENOPAUSE: A SYSTEMATIC REVIEW Alexsandra Ribeiro Ferreira, Laura Faustino Gonçalves, Karina Mary de Paiva, Ana Ines Gonzales, Patricia Haas

Figure 1. Flowchart of the search process
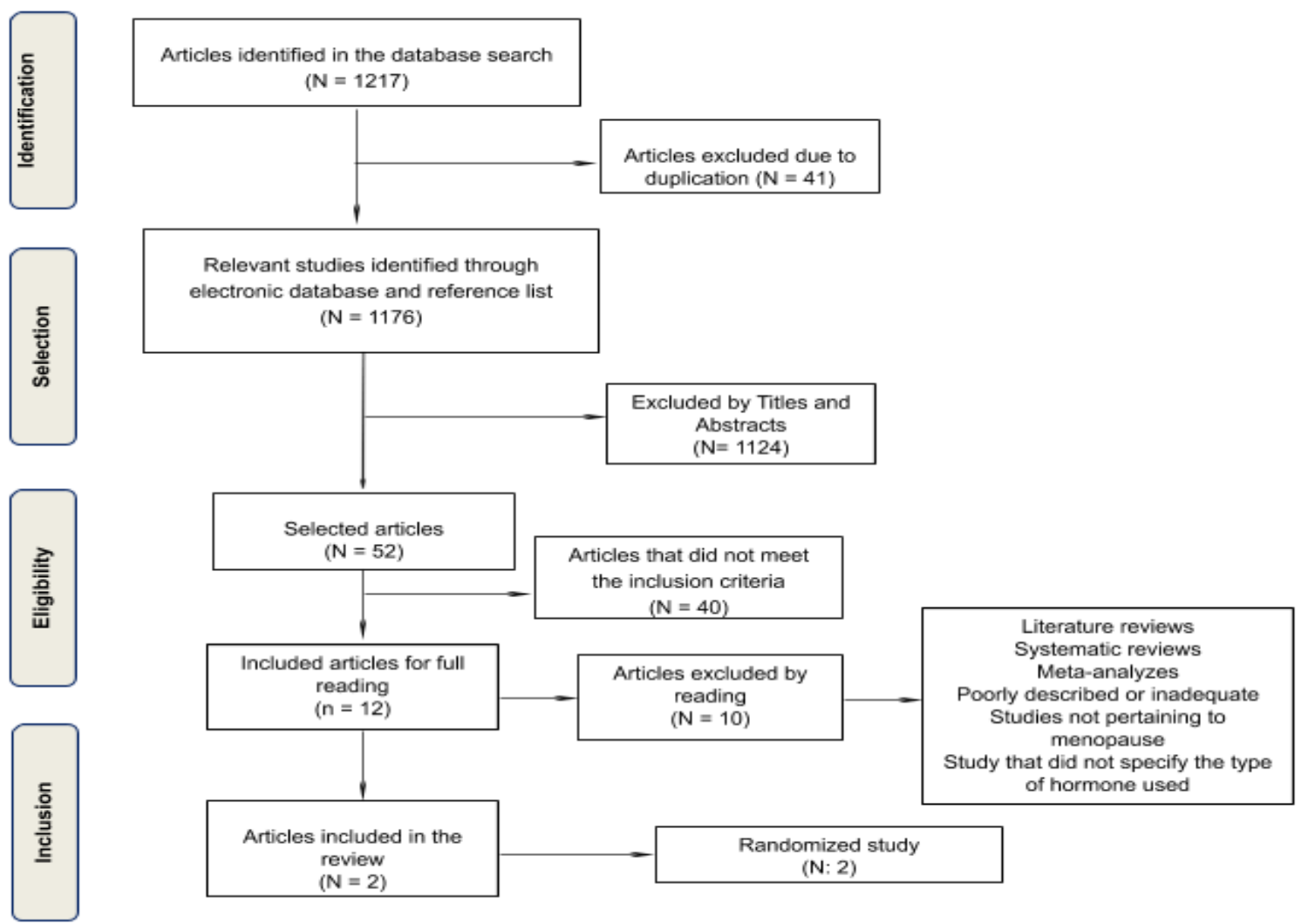

Source: Developed by the authors.

\section{Study Description}

The two studies analyzed were of the randomized controlled study type. In the study by Fahlén et al (2011) [14] 75 women under the age of 70 were randomized, the sample was divided into four groups, in Group 1a and 1b, there were 38 women and in Group 2a and $2 b 37$ participants, in both participating groups reported breast cancer treated previously, with no recurrence of breast cancer.

In the study by Manson et al (2013) [15], a sample composed of 27,347 postmenopausal women aged 50 to 79 years was evaluated for an average period of five years. The sample was divided into four groups, Group 1a and 1b consisted of 16,608 women with an intact uterus, and Group 2a and 2b 10,739 women with a history of uterine cancer, with no history of breast cancer. In both studies, the type of neoplasia among the participants was not specified. Table 3 shows the indicative information for each study regarding the variables, type of study, treatment, frequency of treatment, evaluation, assessment instruments and results. 


\section{RECIMA21 - REVISTA CIENTÍFICA MULTIDISCIPLINAR ISSN 2675-6218}

QUALITY OF LIFE RELATED TO BREAST CANCER IN WOMEN IN POSTMENOPAUSE: A SYSTEMATIC REVIEW Alexsandra Ribeiro Ferreira, Laura Faustino Gonçalves, Karina Mary de Paiva, Ana Ines Gonzales, Patricia Haas

\section{Therapeutics used in studies}

In the study by Fahlén et al (2011) ${ }^{[14]}$, the authors aimed to assess the effects of HT on menopause on QOL in women after breast cancer. The sample of 75 women was divided into four groups, and in Group 1a and 1b, 38 women used HT with $2 \mathrm{mg}$ of estradiol combined with progestogens daily, and in Group 2a and 2b, 37 women were used as controls, without no hormonal treatment. In addition, 67\%, 25 patients in group $1 \mathrm{~b}$ and 25 in group $2 \mathrm{~b}$, used tamoxifen orally as an adjunct to treatment.

The study by Mason et al (2013) ${ }^{[15]}$ aimed to assess the effects of HR with post-intervention monitoring of hormonal therapy in a four groups (1a, 1b, 2a and 2b). In group 1a, women with an intact uterus were inserted, who used Conjugated Equine Estrogens (CEE) for oral use administered at 0.625 $\mathrm{mg}$ daily, associated with the use of Medroxyprogesterone Acetate (MPA) at $2.5 \mathrm{mg}$ daily, in group $1 \mathrm{~b}$ there were women with an intact uterus, who used only placebo (formulation without pharmacological effect). Group 2a, on the other hand, composed of women with a history of hysterectomy, used only oral CEE at $0.625 \mathrm{mg}$ per day and, in group $2 \mathrm{~b}$, women who used only placebo.

\section{Quality of life assessment}

Regarding QOL assessment, Fahlén et al (2011) $)^{[14]}$ used two questionnaires, the European Organization for Research and Treatment of Cancer Core Quality of Life Questionnaire (EORTC QLQC30) and the Quality of Life Questionnaire Breast Cancer - 23 (QLQ- BR23). Regarding the results obtained, no significant differences were found between the groups at the beginning of treatment, however there was a marked improvement throughout the treatment, where there was an increase of 13.6 points in the QOL scale after 12 months of using the hormonal therapy, while in the group without the use of $\mathrm{HT}$, variance was observed only in the anxiety sub items. 


\section{RECIMA21 - REVISTA CIENTÍFICA MULTIDISCIPLINAR} ISSN 2675-6218

QUALITY OF LIFE RELATED TO BREAST CANCER IN WOMEN IN POSTMENOPAUSE: A SYSTEMATIC REVIEW Alexsandra Ribeiro Ferreira, Laura Faustino Gonçalves, Karina Mary de Paiva, Ana Ines Gonzales, Patricia Haas

Table 3: Characteristics of the selected articles.

\begin{tabular}{|c|c|c|c|c|c|c|}
\hline $\begin{array}{l}\text { Author / } \\
\text { Year / } \\
\text { Country }\end{array}$ & $\begin{array}{l}\text { Study } \\
\text { type / } \\
\text { score }\end{array}$ & $\begin{array}{c}\text { Treatme } \\
\text { nt }\end{array}$ & $\begin{array}{c}\text { Frequen } \\
\text { cy }\end{array}$ & $\begin{array}{l}\text { Assess } \\
\text { ments }\end{array}$ & $\begin{array}{c}\text { Assess } \\
\text { ment } \\
\text { Instru } \\
\text { ments }\end{array}$ & Results \\
\hline $\begin{array}{c}\text { MANSON } \\
\text { et al./ } \\
2013 / \\
\text { Boston }\end{array}$ & $\begin{array}{l}\text { Randomi } \\
\text { zed } \\
\text { clinical } \\
\text { trial } \\
\text { Pithon: } \\
11 / 13\end{array}$ & $\begin{array}{l}\text { CEE + } \\
\text { MPA or } \\
\text { placebo; } \\
\text { CEE } \\
\text { alone or } \\
\text { placebo. }\end{array}$ & $\begin{array}{l}\text { Daily } \\
\text { CEE } \\
\text { dose of } \\
0.625 \mathrm{mg} \\
\text { / day and } \\
2.5 \mathrm{mg} / \\
\text { day. }\end{array}$ & $\begin{array}{l}\text { Evaluatio } \\
\mathrm{n} \text { of } \\
\text { quality of } \\
\text { life, } \\
\text { cognitive } \\
\text { and } \\
\text { cancer } \\
\text { incidence } \\
\text { after } \\
\text { interventi } \\
\text { on. }\end{array}$ & RAND. & $\begin{array}{l}\text { Significant improvement in vasomotor } \\
\text { symptoms was observed in women who } \\
\text { used combined hormone therapy, when } \\
\text { comparing those who used estrogen } \\
\text { alone. } \\
\text { For the group treated with CEE, a risk of } \\
1.28 \% \text { of the patient's risk of developing } \\
\text { breast cancer was observed, while in } \\
\text { the group treated with CEE alone, a } \\
\text { reduction of } 0.79 \% \text { was observed to } \\
\text { develop the disease. } \\
\text { However, even after the interruption in } \\
\text { the use of hormonal treatment, new } \\
\text { cases of breast cancer were evidenced. }\end{array}$ \\
\hline $\begin{array}{l}\text { FAHLÉN et } \\
\text { al./ } 2011 / / \\
\text { Sweden }\end{array}$ & 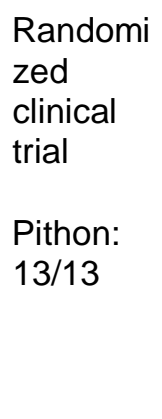 & $\begin{array}{l}\text { Estradiol } \\
+ \\
\text { progesto } \\
\text { gen; } \\
\text { Estradiol } \\
+ \\
\text { progesto } \\
\text { gen }+ \\
\text { tamoxife } \\
\text { n. }\end{array}$ & $\begin{array}{l}2 \mathrm{mg} \text { of } \\
\text { estradiol } \\
\text { combined } \\
\text { with daily } \\
\text { progesto } \\
\text { gen. }\end{array}$ & $\begin{array}{l}\text { Quality of } \\
\text { life, } \\
\text { anxiety } \\
\text { and } \\
\text { depressi } \\
\text { on, and } \\
\text { functiona } \\
\text { I } \\
\text { symptom } \\
\text { s. }\end{array}$ & $\begin{array}{l}\text { EORTC } \\
\text { QLQ- } \\
\text { C30, } \\
\text { QLQ- } \\
\text { BR23, } \\
\text { HADS. }\end{array}$ & $\begin{array}{l}\text { For the group using hormonal therapy, } \\
\text { there was a significant improvement in } \\
\text { relation to insomnia, as well as in } \\
\text { anxiety, depression and emotional } \\
\text { functions. } \\
\text { However, when combined HT was } \\
\text { associated with the use of Tamoxifen, a } \\
\text { significant improvement in the quality of } \\
\text { life of patients was observed. }\end{array}$ \\
\hline
\end{tabular}

Legend: CEE: Conjugated Equine Estrogens; MPA: Medroxyprogesterone Acetate; European Organization for Research and Treatment of Cancer Core Quality of Life Questionnaire, QLQ-BR23: Quality of Life Questionnaire Breast Cancer - 23; HADS: Hospital Anxiety and Depression Scale; HT: Hormone Therapy.

However, of the $33.3 \%$ of patients who were using only tamoxifen, lower levels of anxiety and emotional function were observed when compared to those without the use of the drug. However, after one year of use, no additional benefits were seen among women who used tamoxifen, in addition to those already mentioned. On the other hand, when using HRT with estrogen and progesterone, there were numerous positive effects reported, such as the $6.8 \%$ improvement in body image and $18.2 \%$ for the sexual pleasure item, demonstrating an improvement in the overall quality of life of the woman patients ${ }^{[14]}$.

In the study by Mason et al (2013) ${ }^{[15]}$, quality of life was assessed using the RAND 36-Item Short Form Health Survey, in which it was observed that treatment with EEC associated with the use of MPA resulted in statistically significant benefits after one year after intervention in relation to physical functioning, body pain and general health, when compared to the group treated only with placebo. In 


\section{RECIMA21 - REVISTA CIENTÍFICA MULTIDISCIPLINAR ISSN 2675-6218}

QUALITY OF LIFE RELATED TO BREAST CANCER IN WOMEN IN POSTMENOPAUSE: A SYSTEMATIC REVIEW Alexsandra Ribeiro Ferreira, Laura Faustino Gonçalves, Karina Mary de Paiva, Ana Ines Gonzales, Patricia Haas

addition, the group treated with isolated EEC alone was associated with a greater number of negative events in relation to emotional and social function in the scores assessed by the QOL scale.

\section{Secondary outcomes}

In the study by Manson et al $(2013)^{[15]}$, the results showed that $38.7 \%$ of women in group 1a treated with HT with SCC + MPA reported feeling some mild, moderate or severe vasomotor symptom at the beginning of treatment, in the however, after five years of intervention, symptoms were reported in only $16.36 \%$ of cases. In group $2 \mathrm{a}$, treated only with SCC before the intervention, vasomotor symptoms were prevalent in $43.6 \%$ and, after treatment, they were reported in only $29.15 \%$ of cases. In both groups 1a and $2 \mathrm{a}$, there was an improvement in vasomotor symptoms, however, these results demonstrate a significant improvement of these symptoms in patients in group 1a, treated with conjugated estrogen plus the use of medroxyprogesterone.

Fahlén et al (2011) ${ }^{[14]}$ used the Hospital Anxiety and Depression Scale (HADS), aimed at assessing the anxiety and depression of non-psychiatric patients. As a result of the study, patients in groups $1 \mathrm{a}$ and $1 \mathrm{~b}$ had 8 points on the scale of sub-items assessed by HADS at the beginning of treatment, with an improvement in the score to 4.5 points after 12 months of intervention for the items anxiety, depression, emotional functions, cognitive and social and global quality of life. In the group without the use of HRT, groups $2 \mathrm{a}$ and $2 \mathrm{~b}$, a reduction from 7 points to 5.5 points on the HADS scale was observed after one year of intervention. Another data evaluated in the study by Mason et al $(2013)^{[15]}$, was the Body Mass Index (BMI), in which $38.8 \%$ had a $\mathrm{BMI} \geq 30$, while $26.6 \%$ had a $\mathrm{BMI}<25$, that is, the study sample ranged from adequate weight to grade I obesity.

As for the health risk assessment, the results of this same study ${ }^{[15]}$, showed that during the postintervention phase the results remained statistically significant, with a $1.28 \%$ relative risk of developing breast cancer in the group treated TPH with CCE + MPA, in addition to a significant relationship between the patient's age and the risk of developing the disease, when older women had higher risks when compared to younger women. However, for the group treated with estrogen alone, a reduction in the risk of developing breast cancer was observed in $0.79 \%$ of cases. It is noteworthy that, even after interrupting the use of therapy, cases of breast cancer diagnosis were reported among women in group 1 a.

Another data analyzed dealt with the patients' risk of developing endometrial cancer, in which it was verified that after cessation of use, there was a $0.3 \%$ drop in the risk of developing cancer in group $1 \mathrm{a}^{[15]}$. In the study by Fahlén et al $(2011)^{[14]}$, no recurrence of breast cancer was reported among women in groups $1 \mathrm{a}$ and $1 \mathrm{~b}$, using $\mathrm{HT}$. 


\section{RECIMA21 - REVISTA CIENTÍFICA MULTIDISCIPLINAR ISSN 2675-6218}

QUALITY OF LIFE RELATED TO BREAST CANCER IN WOMEN IN POSTMENOPAUSE: A SYSTEMATIC REVIEW Alexsandra Ribeiro Ferreira, Laura Faustino Gonçalves, Karina Mary de Paiva, Ana Ines Gonzales, Patricia Haas

\section{DISCUSSION}

The purpose of this research was to search for and analyze scientific evidence on the effects of hormone therapy on breast cancer in menopause. The studies analyzed in this research ${ }^{[14,15]}$, showed marked vasomotor symptoms in both samples and, a significant improvement after the use of HT, included in the patients' quality of life. However, in only one of the studies ${ }^{[15]}$, it was found that even after the treatment ceased, the risks of developing breast cancer remained relatively high, in addition to the risk of developing endometrial cancer among women.

According to the Ministry of Health, among the main risk factors for developing breast cancer are age, family and personal history, lifestyle, obesity, hormonal therapy, among others ${ }^{[16]}$. In a crosssectional case-control study carried out in Bahia, the authors verified the association between body mass index and breast cancer. In this study, with 190 participants, where $70.8 \%$ of the study sample was in menopause and only $30.9 \%$ used HT. A great relationship was observed between obesity and the occurrence of breast cancer among women, indicating overweight as a risk factor for developing breast cancer ${ }^{[18]}$.

In line with this finding, in one of the studies the Body Mass Index (BMI) $\geq 30$ was observed in most of the sample, $38.8 \%$ had grade I obesity, demonstrating another risk factor favorable to the occurrence of the disease ${ }^{[15,16]}$. In addition, according to the literature, women who are physically active have a lower risk of developing the disease when compared to sedentary women ${ }^{[18]}$. If we analyze the risk factors established in this study, the chances of a woman in menopause to develop breast cancer can be increased by the number of factors in this population, such as age, obesity and the use of HT.

Regarding the use of hormone therapies, Fournier, Berrino and Clavel-chapelon ${ }^{[19]}$, through a prospective cohort study, investigated the risk factors for cancer in women in the metropolitan region of France. In this study, approximately one million volunteers participated, aged between 40 and 65 years, where $70 \%$ used HT for an average period of seven years. A higher relative risk of developing the disease was observed among women who used hormonal therapy, being possible to observe it before two years of use, when compared with those women who never used the hormone. In addition, there was a significant increase in risk among women who used estrogen plus different progestogens, when compared to those who used estrogen alone.

Similar data to the study by Fournier, Berrino and Clavel-chapelon ${ }^{[19]}$ were found in our review, where greater risks of developing breast cancer were found among women who used estrogen combined with different progestogens. Despite the data found in this review, it is at odds with those reported by the National Cancer Institute $(\mathrm{INCA})^{[20]}$, where the risk of developing a disease decreases progressively after discontinuation of $\mathrm{HT}$. Among the studies analyzed, disease diagnostic tests were reported after the hormone was stopped, showing that minimal exposure to hormone therapy can increase a woman's risk of developing breast cancer. 


\section{RECIMA21 - REVISTA CIENTÍFICA MULTIDISCIPLINAR ISSN 2675-6218}

QUALITY OF LIFE RELATED TO BREAST CANCER IN WOMEN IN POSTMENOPAUSE: A SYSTEMATIC REVIEW Alexsandra Ribeiro Ferreira, Laura Faustino Gonçalves, Karina Mary de Paiva, Ana Ines Gonzales, Patricia Haas

Although some authors report disagreement in the relationship between the use of HT and breast cancer ${ }^{[8]}$. In a population-based case control study carried out in the United States, with 1,044 patients aged 55 to 74 years old, they aimed to assess the relationship between the use of $\mathrm{HT}$ and cases of breast cancer. In this study, the authors evidenced 2.7 and 3.3 times more risks of lobular and ducto-lobular carcinoma, respectively, regardless of tumor stage, size or nodal status. In addition, the increase in risk indices was evidenced in users who used estrogen and progestogen combined for a period of three years, and no relevant evidence was found after use for longer periods ${ }^{[21]}$.

Although the studies analyzed in this review do not specify the type of cancer prevalent among the participants, the data presented by a study in the literature indicates the risks and benefits of using $\mathrm{HT}$ among women. Among the benefits mentioned are the decrease in the occurrence of osteoporosis and coronary heart disease, however, the risks of using this therapy include the occurrence of venous thromboembolism, especially when combined with the progestogen ${ }^{[22]}$. Therefore, the results of this study prove to be plausible that the use of hormone therapy can increase the risk of women developing breast cancer during menopause. This index may change depending on method hormone used, the woman's age and, especially, the time of hormone use, where a considerable increase in the risk of developing breast cancer in women using hormone therapy for prolonged periods is observed.

\section{CONCLUSION}

As discussed in the present study, the use of HT presents risks and benefits during menopause. As a benefit, we can mention the treatment and prevention of osteoporosis and reduction of vasomotor symptoms, directly interfering in the quality of life of women. As health risks for women, many authors point out divergences regarding the use of hormone therapy and the development of breast cancer in menopausal women, despite strong evidence regarding the risk factors for the occurrence of the disease, especially in women aged more advanced.

As for the applicability of $\mathrm{HT}$ in women with risk factors for the occurrence of breast cancer, the use of combined hormonal therapy is not recommended, since the rates of disease development were higher in women who had a risk factor for the disease despite this, lower rates of breast cancer risk were observed when hormone therapy was administered with estrogen alone.

The diagnosis of breast cancer is performed through detection tests such as breast self-examination, mammography with abdominal protection, which must be complemented with breast ultrasonography due to inconclusive results of the imaging exam due to the physiological changes of the breast, for a conclusive diagnosis breast biopsy in addition to MRI can also be performed.

The delay in the diagnosis of cancer and the effects of the treatment end up causing physical mutilations and changes in lifestyle. Finally, use for a period of more than five years is not indicated by scientific evidence, since in the studies analyzed, the time of use directly influenced the occurrence of the disease. 


\title{
RECIMA21 - REVISTA CIENTÍFICA MULTIDISCIPLINAR ISSN 2675-6218
}

\author{
QUALITY OF LIFE RELATED TO BREAST CANCER IN WOMEN IN \\ POSTMENOPAUSE: A SYSTEMATIC REVIEW \\ Alexsandra Ribeiro Ferreira, Laura Faustino Gonçalves, \\ Karina Mary de Paiva, Ana Ines Gonzales, Patricia Haas
}

\section{REFERENCES}

1. World Health Organization. Cancer Overview: Breast cancer. World Health Organization. Geneva: Switzerland; 2020. https://www.who.int/cancer/prevention/diagnosis-screening/breastcancer/en/.

2. Instituto Nacional de Câncer José Alencar Gomes da Silva. Estimativa 2020: incidência de câncer no Brasil / Instituto Nacional de Câncer José Alencar Gomes da Silva. Rio de Janeiro: INCA; 2019.

3. Lui Filho JF, Baccaro LFC, Fernandes T, Conde DM, Costa-Paiva L, Pinto NAM. Epidemiologia da menopausa e dos sintomas climatéricos em mulheres de uma região metropolitana no sudeste do Brasil: inquérito populacional domiciliar: inquérito populacional domiciliar. Revista Brasileira de Ginecologia e Obstetrícia. 2015. Abr;37(4):152-158. DOI: http://dx.doi.org/10.1590/s0100-720320150005282.

4. Oliveira J, Chaves A. O uso da terapia de reposição hormonal em mulheres na pósmenopausa. Infarma - Ciências Farmacêuticas. 2012 dec;23(9/12):15-22. ISSN 2318-9312. Disponível em: http://revistas.cff.org.br/?journal=infarma\&page=article\&op=view\&path\%5B\%5D=20.

5. Ferreira ICC, Almeida RS, Silva SS. Menopausa, sinais e sintomas e seus aspectos psicológicos em mulheres sem uso de reposição hormonal. Rev Ensaios Cienc Biol Agrar Saúde. 2015;19:60-4.

6. Trench B, Santos CG. Menopausa ou Menopausas? Saúde e Sociedade. 2005 Abr;14(1): 91100. DOI: http://dx.doi.org/10.1590/s0104-12902005000100010.

7. Oliveira VM, Aldrighi JM, Gebara OC. E agora, José? Como ficam os riscos do câncer de mama e do infarto do miocárdio nas usuárias da terapia hormonal após a menopausa? Revista da Associação Médica Brasileira. 2011 Jul;57(4):361-364. DOI: http://dx.doi.org/10.1590/s0104$\underline{42302011000400003}$.

8. Pardini D. Terapia de reposição hormonal na menopausa. Arquivos Brasileiros de Endocrinologia \& Metabologia. 2014 mar;58(2)172-181. DOI: http://dx.doi.org/10.1590/0004$\underline{2730000003044 .}$.

9. Rossouw JE, Anderson GL, Prentice RL et al. Risks and benefits of estrogen plus progestin in healthy postmenopausal women: principal results From the Women's Health Initiative randomized controlled trial. JAMA. 2002;288(3):321- 333. DOI: doi:10.1001/jama.288.3.321

10. Kenemans P, Kubista E, Foidart JM et al. Safety of tibolone in the treatment of vasomotor symptoms in breast cancer patients--design and baseline data 'LIBERATE' trial [published correction appears in Breast. 2008 Apr;17(2):214-5. Egberts J [added]; van Os, S [added]; Planellas, J [added]]. Breast. 2007;16 Suppl 2:S182- S189. doi:10.1016/j.breast.2007.07.028

11. Wender MCO, Pompei LM, Fernandes CE. Consenso Brasileiro de Terapêutica Hormonal da Menopausa - Associação Brasileira de Climatério (SOBRAC) - São Paulo: Leitura Médica; 2014.

12. Moher D, Shamseer L, Clarke M, Ghersi D, Liberati A, Petticrew M, Shekelle P, A Stewart L. Preferred reporting items for systematic review and meta-analysis protocols (PRISMA-P) 2015 statement. Systematic Reviews. 2015 jan;4(1):1-9. DOI: http://dx.doi.org/10.1186/2046-4053-4-1.

13. Pithon MM, Sant'Anna LI, Baião FC, Santos RL, Coqueiro RS, Maia LC. Assessment of the effectiveness of mouthwashes in reducing cariogenic biofilm in orthodontic patients: a systematic review. J Dent. 2015;43:297-308.

14. Fahlén M, Wallberg B, Von Schoultz E, Carlström K, Svensson G, Wilking N, et al. Healthrelated quality of life during hormone therapy after breast cancer: a randomized trial: a randomized trial. Climacteric. 2011 fev;1:164-170. DOI: http://dx.doi.org/10.3109/13697131003660593. 


\section{RECIMA21 - REVISTA CIENTÍFICA MULTIDISCIPLINAR ISSN 2675-6218}

QUALITY OF LIFE RELATED TO BREAST CANCER IN WOMEN IN POSTMENOPAUSE: A SYSTEMATIC REVIEW Alexsandra Ribeiro Ferreira, Laura Faustino Gonçalves, Karina Mary de Paiva, Ana Ines Gonzales, Patricia Haas

15. Manson JE, Chlebowski RT, Stefanick ML et al. Menopausal Hormone Therapy and Health Outcomes During the Intervention and Extended Poststopping Phases of the Women's Health Initiative Randomized Trials. Jama. 2013 out;310(13):1353-1368. DOI: http://dx.doi.org/10.1001/jama.2013.278040.

16. World Health Organization. Physical status: the use and interpretation of anthropometry. Geneva: WHO; 1995.

17. Brasil. Ministério da Saúde. Secretaria de Atenção à Saúde. Departamento de Ações Programáticas Estratégicas. Manual de Atenção à Mulher no Climatério/Menopausa / Ministério da Saúde, Secretaria de Atenção à Saúde, Departamento de Ações Programáticas Estratégicas. Brasília: Editora do Ministério da Saúde; 2008

18. Pinheiro AB, Barrero-Neto NJS, Rio JA, Crusoé NSDR, Pinto RMO, Santos IO. et al. Associação entre índice de massa corpórea e câncer de mama em pacientes de Salvador, Bahia. Rev Bras Mastologia. 2014;24(3):76-81.

19. Fournier Agnès, Berrino Franco, Clavel-Chapelon Françoise. Unequal risks for breast cancer associated with different hormone replacement therapies: results from the e3n cohort study: results from the E3N cohort study. Breast Cancer Research And Treatment. 2007 fev;107(1):103-111. DOI: http://dx.doi.org/10.1007/s10549-007-9523-x.

20. BRASIL. Ministério da Saúde. Instituto Nacional do Câncer. Câncer de mama: é preciso falar disso. Rio de Janeiro: Inca; 2014.

21. Li Cl, Malone KE, Porter PL, Weiss NS, Tang MT, CushingHaugen KL. et al. Relationship between long durations and different regimens of hormone therapy and risk of breast cancer. JAMA 2003;289:3254-63.

22. Souza NRR, Viana MEL, Miranda MLC, De Miranda ML, De Souza JHK. Relação entre terapia de reposição hormonal no climatério e o desenvolvimento de neoplasias. Repositório Institucional, Universidade Federal de Ouro Preto. 2019;25(2):135-143. 